B 61 縌陑奇形腫原発が疑われた墨性黑色腫と横 紋筋肉腫の1例

国療刀根山病院外科豊中市民病院病理 *

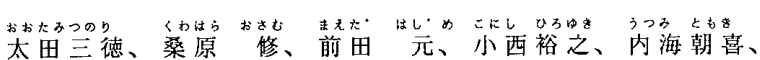

【症例】25歳男、既往歴・家族歴に特記する屯のなし. 1994 年 3 月に左胸痛と学作時呼吸困難を自覚し、近医受 部、胸部写真にて左上肺野の陰影を指摘され、当科紹介 となる。4月1日入院時, 体温 $38 \sim 39$ 度 C, 血圧正常, 頻脈 $(100 /$ 分), 頚部 /腋下リンパ節は触知せず, 左肺呼吸音は 微弱.一般榆查では白血球 $9700 / \mathrm{mm}^{3}$ と軽度上昇，血小板 50 万 $/ \mathrm{mm}^{3}$ 亡上舁. 血液化学ではLDHが $1763 \mathrm{IU} / \mathrm{L}$ 高值で, 血清学的にはCRP $12.7 \mathrm{mg} / \mathrm{d} 1$ と高值, CEA, AFP, SCCは正常 範国, $\mathrm{HCG}$ は正常であるが HCG- $\beta$ は $0.36 \mathrm{ng} / \mathrm{ml}(<0.1)$ と 軽度上昇していた，胸部写真、C Tでは左全胸腔を占め, 多胞性の構造を持ち、上前緃淂からの発生を疑った. 4 月 8 日前胸部からの開胸生検で未分化癌の讋断を得, 胚細 胞腫の可能性も考虑し, PEB療法 (CDDP + VP-16+BLM：4w每, 3 了ース) と Liniac照射 (計 $33 \mathrm{~Gy}$ )を施行した. 画像上腫瘍は 著しく縮小し, LDHの低下も得たので, 7月12日左胸膜脯 全摘，左横隔膜切除，心膜切除，縦隔及び後腹膜りンパ節切 除を施行した。術後, 敗血症となり8月9日死去された。病 理所見では成熟奇形腫内に悪性黑色腫亡横紋筋肉腫を 認め，悪性組織が奇形腫発生であることが推測された。 本疾患の治療と組織発生について考察し，報告する。

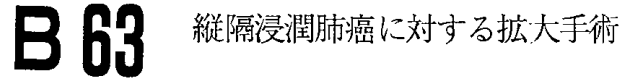

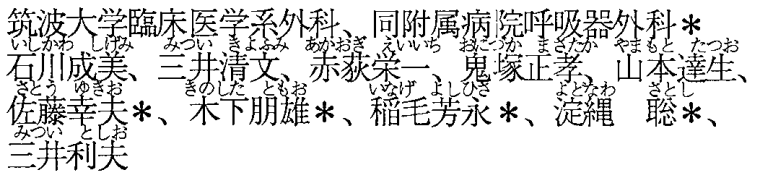

【目的】肺癌根治手術の問題点として、合併切除を要 する拡大手術の適忍となる縱隔浸潤肺癌の切除がある。 絴隔浸潤肺癌の手術成績と、その適芯を検討する。

【刘象】1993年までの当科の肺癌切除 669 例中、病 理組織で䋊隔浸潤を認めた 87 例（13\%）を対象と した。扁平上皮癌 48 例、腺癌 23 例、ほか 16 例で あった。術式は、肺全摘が 4 例、肺葉切除 38 例、 区域切除 2 例、肺部分切除 3 例であり、合併切除は上 大静脈 (S V C) 10 例、大動脈外膜 13 例、左房 29 例、心膜 19 例、椎体 2 例、食道筋層 10 例、気 管分肢部 9 例であった。手術根治度は、相対的治癒切 除 40 例、非治瘉切除 47 例であった。

【結果】縦隔浸潤肺癌切除例の 5 年生存率は $7 \%$ であっ た。癌死は 45 例、うち局所再発が 25 例、遠隔転移 が2 2 例、また術死は 5 例であった。3 年以上生存は 15 例 (16\%) で、このうち扁平上皮癌が 11 例、 相対的治瘉切除がなされたものが 10 例であった。

【結語】䋊隔浸潤肺癌のうち、扁平上皮癌に対しては 拡大手術による治癒切除を行うことで良好な予後が期 待できると考えられる。
B $6 \boldsymbol{2}^{\text {気道狭窄症状で発症した肺原発線維肉腫 }}$

静岡済生会総合病院 呼吸器外科

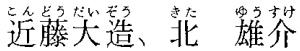

きわめてまれな肺原発線維肉腫を経験したので報告 する。

患者は79嵅、女性。高度呼吸困難を主訴に、救急外 来受診し入院となった。精查にて左肺上葉腫瘍から気 管支内腔をポリープ状に增殖し、先端は気管分岥部を 超え、気道を狭窄しているのを確認した。気管支拡張 梸とステロイドにて呼吸苦は軽快したので、 3 日後、 経気管支鏡的レーザー㜔却法にて気道狭窄を解除し、 全身検索を施行したところ、c-T 4 N O M N の 左上葉原発 肺癌之診断。組織診断は気管支鏡下生検にて非上皮性 腫湟を疑った。19日後、左肺全摘、R2aを施行した。 病埋診断は、線維肉腫で、 $\mathrm{p}$ - T2 $2 \mathrm{No} \mathrm{M}$ o、1期であった。

肺原発線維肉腫の頻度はきわめてまれであり、肺原 発の肉腫には、太い気管支加発生し、内腔にボリー プ状に增殖するものと、末梢に発生し境界明瞭な腫熘 を形成するものとがあるが、本例は、末梢に発生し、ポ リープ状に気管分岐部を超えて内腔を増殖してきたもの と思われた。重篤な症状で発症し、巨大腫瘍であった が、病理病期は 1 期であった。また、このような気道 狭窄を呈する肺癌に対し、レーザー（特に今回用いた contact laser)により気道を確保することは、以後の 診療が安全に遂行でき、たいんん有用と思われた。

\section{R4 超高齢者肺癌に対する外科治療の適応と術後 合併症の検討}

金沢大学医学部第一外科

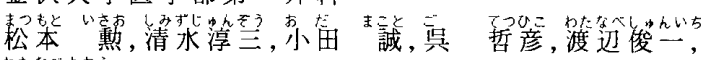

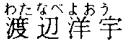

【目的】 80 歳以上の超高齿者肺癌に対する手術適応と 術後合併症について検討した。【対象】1973〜 84年の 22年問に手術した肺癌1284例のうち, 80 歳以上の超高齢 者肺癌20例 (1.5\%) を対象とした。男 13 ,女 7 例.年齢は 80 $\sim 85$ (平均 81.5) 歳。組織型は扁平 6 , 腺 10 , 大 1 , 小 2 例。病 期は I 期 11, II 期 2, II A 期 5, IV 期 2例。根治度は絶治 2 , 相 治 2 , 相非 13 , 絶非 3 例と非治癒切除が多数を占めた。手術 適応として, 術前の呼吸機能検査で $\mathrm{FEV}$ 1。が1.0L以上, PSが0〜1とした。さらに階段を界る際に患者に動悸や息 切れがないことを確認した。合併症対策として術前・術 後を通じて徹底的な呼吸リハビリを導入した。【結果】 (1)術前の呼吸機能は平均\%VC $90.7( \pm 18.6) \%, \mathrm{FEV}_{1}$ 。 1.60( \pm 0.48$) \mathrm{L}$ であった. (2) 手術死はなく,20例中 4 例が 生存中 (最長 77 力) で, 16 例が平均 23.1 力月で死亡した。 (3)部切および区切の3生率 $33.3 \%, 5$ 生率 $22.2 \%$ で, 一葉切 除以上の 3 生率 $38.1 \%, 5$ 生率 $19.0 \%$ と比較して遜色なかっ た。(4)合併症は11例 (55\%) と高率に認め, 痴呆や肺胞瘻遷 延等が特徵的であった。【結語】超高齢者肺癌では緟格 に手術適応を決定し，縮小手術を第一選択とすべきであ る.また術式は部切または区切で十分であり,胸燃鏡手 術が有効な症例もあると考えられる。 